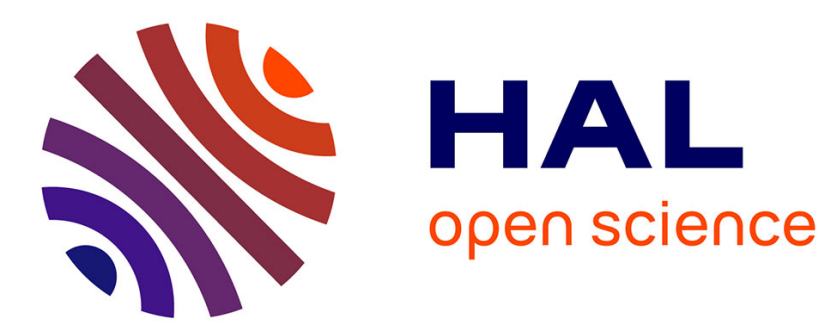

\title{
Ghrelin in mental health, sleep, memory
}

Axel Steiger, Martin Dresler, Petra Schüssler, Michael Kluge

\section{To cite this version:}

Axel Steiger, Martin Dresler, Petra Schüssler, Michael Kluge. Ghrelin in mental health, sleep, memory. Molecular and Cellular Endocrinology, 2011, 340 (1), pp.88. 10.1016/j.mce.2011.02.013 . hal00706319

\section{HAL Id: hal-00706319 \\ https://hal.science/hal-00706319}

Submitted on 10 Jun 2012

HAL is a multi-disciplinary open access archive for the deposit and dissemination of scientific research documents, whether they are published or not. The documents may come from teaching and research institutions in France or abroad, or from public or private research centers.
L'archive ouverte pluridisciplinaire HAL, est destinée au dépôt et à la diffusion de documents scientifiques de niveau recherche, publiés ou non, émanant des établissements d'enseignement et de recherche français ou étrangers, des laboratoires publics ou privés. 


\section{Accepted Manuscript}

Title: Ghrelin in mental health, sleep, memory

Authors: Axel Steiger, Martin Dresler, Petra Schüssler, Michael Kluge

PII: $\quad$ S0303-7207(11)00121-3



DOI: doi:10.1016/j.mce.2011.02.013

Reference: $\quad$ MCE 7776

To appear in: $\quad$ Molecular and Cellular Endocrinology

Received date: $\quad 2-12-2010$

Revised date: $\quad 15-2-2011$

Accepted date: $\quad$ 15-2-2011

Please cite this article as: Steiger, A., Dresler, M., Schüssler, P., Kluge, M., Ghrelin in mental health, sleep, memory, Molecular and Cellular Endocrinology (2010), doi:10.1016/j.mce.2011.02.013

This is a PDF file of an unedited manuscript that has been accepted for publication. As a service to our customers we are providing this early version of the manuscript. The manuscript will undergo copyediting, typesetting, and review of the resulting proof before it is published in its final form. Please note that during the production process errors may be discovered which could affect the content, and all legal disclaimers that apply to the journal pertain. 
Ghrelin in mental health, sleep, memory

Axel Steiger ${ }^{1}$, Martin Dresler ${ }^{1}$, Petra Schüssler ${ }^{1}$, Michael Kluge ${ }^{1,2}$

${ }^{1}$ Max Planck Institute of Psychiatry, Munich, Germany

${ }^{2}$ Department of Psychiatry, University of Leipzig, Leipzig, Germany

in: Molecular and Cellular Endocrinology -

Special Issue: Ghrelin and Disease - revised -

MS MCE-D-10-00518

Corresponding author:

Axel Steiger M.D.

Max Planck Institute of Psychiatry

Department of Psychiatry

Kraepelinstrasse 2-10

80804 Munich

Germany

Tel.: ++49-89-30622-236

Fax: ++49-89-30622-552

E-mail: steiger@mpipsykl.mpg.de 


\section{Abstract}

Ghrelin acts as a neuropeptide. It participates in sleep-wake regulation. After systemic ghrelin treatment nonREM sleep is promoted in male humans and mice. This effect is influenced by gender, time of administration and depression. Ghrelin does not modulate sleep in healthy women and during the early morning in male subjects. In depressed women REM sleep is diminished after ghrelin. In elderly men and depressed men sleep promotion by ghrelin was preserved. In rats after central ghrelin feeding and wakefulness increased. The nocturnal secretion pattern of cortisol, GH, LH, FSH and hypothalamo-pituitary-thyroid hormones are influenced by ghrelin. Furthermore ghrelin appears to be related to memory and to be involved in the pathophysiology of CNS disorders, particularly depression.

Keywords: ghrelin, sleep, depression, memory, mental health 


\section{Introduction}

The early observation that ghrelin, besides stimulating the release of growth hormone (GH) and other hormones (Kojima et al., 1999) enhances feeding in the rat (Tschöp et al., 2000;Wren et al., 2000) suggests that it acts as a neuropeptide. In humans ghrelin stimulates appetite (Schmid et al., 2005;Wren et al., 2001). In addition to an increased appetite healthy volunteers reported visual imagination of their favourite meal after a single iv administration of ghrelin (Schmid et al., 2005). Obviously ghrelin affects higher CNS activity and is more than just a signal for hunger. This view is confirmed by various studies during the last decade showing effects of ghrelin on sleep-wake behaviour and memory. Furthermore a role of ghrelin in the pathophysiology of depression and other psychiatric disorders and epilepsy is discussed. The aim of this chapter is to summarize the state of the art in this field.

\section{Ghrelin and sleep}

Ghrelin is the only identified, perhaps the only existing natural ligand of the growth hormone (GH) secretagogue (GHS) receptor (GHSR). The GHSR was cloned before the identification of ghrelin, and synthetic ligands of the GHSR, called GHS were even known before this receptor was cloned. Studies in human volunteers showed effects of synthetic GH on sleep electroencephalogram (EEG). The sleep EEG of mammals contains periods of rapid eye movement (REM) and nonREM sleep. In healthy young subjects nonREM- and REM-sleep periods alternate in a cyclic fashion. NonREM sleep consists of four stages according to the criteria by Rechtschaffen \& Kales (1968). A recent classification (American Academy of Sleep Medicine et al., 2007) differentiates between three stages only. During sleep stage 1 , a transition from drowsiness to light sleep, a slowing of EEG activity occurs. Sleep s pindles and $\mathrm{K}$-complex wave forms are found during sleep stage 2. Synchronised slow waves are found during slow wave sleep (SWS), the sleep stages 3 and 4 (Rechtschaffen \& Kales, 1968) or stage N3 (American Academy of Sleep Medicine et al., 2007) respectively. During REM sleep a faster EEG activity, horizontal rapid eye movements and hypotonus of skeletal muscles are found. In contrast to humans sleep in animals is often polyphasic resulting in episodic sleep-wake patterns. In animals nonREM sleep is not divided into several stages, whereas its depth can be interpreted according to the power of SWS slow wave activity (SWA) (Borbély, 1982). REM sleep is also found in animals. The analysis of eye movements in small animals 
is complicated. Therefore a combination of wake-like EEG with flat electromyogram showing muscle ......... is used to define REM sleep. In humans and animals the microstructure of sleep is investigated by computerized quantitative EEG analysis including amplitudes and power in the EEG bands beta, sigma, alpha, theta and delta (synonymous: SWA). Various factors including monoamines cytokines, neuroactive steroids and peptides participate in sleep regulation (Luppi \& Fort, 2011;Krueger et al., 2011;Steiger, 2007).

In young normal men slow wave sleep (SWS) increased and wakefulness decreased after one week of oral treatment with the GHS MK-677 (Copinschi et al., 1997). This finding is highly interesting as it suggests that oral administration of a neuropeptide is capable of affecting CNS activity. The same authors studied the effects of MK-677 also in a small group of elderly subjects and did not find clear sleep-promoting effects in this age group (Copinschi et al., 1997). GH-releasing peptide-6 (GHRP-6) was given intravenously during sleep via long catheter in a pulsatile fashion (4 bolus injections between 22.00 and $01.00 \mathrm{~h}$ ) (Frieboes et al., 1995). This method appears to be crucial to detect sleep-EEG effects of neuropeptides as it mimics their physiological release (Steiger, 2007). After intravenous GHRP-6 non-rapid eye movement (nonREM) sleep stage 2 increased and the nocturnal secretion of $\mathrm{GH}$, corticotropin (ACTH) and cortisol was elevated. In studies with intranasal, oral and sublingual administration of GHRP-6 the effects on the sleep EEG and hormone secretion were less distinct and partly different from those after intravenous (iv) injection (Frieboes et al., 1999). After hexarelin the amount of SWS decreased, whereas a similar pattern of endocrine effects occurred with a marked stimulation of $\mathrm{GH}$ and an increase of cortisol (Frieboes et al., 2004). The decrease of SWS in this study may be related to negative feedback inhibition of endogenous GH-releasing hormone (GHRH). A single dose injection of GHRP-2 during the third period of rapid eye movement (REM) sleep did not affect sleep (Moreno-Reyes et al., 1998). This method may be insufficient to change sleep EEG.

Ghrelin and GHRH also stimulate the release of GH from the pituitary. GHRH is the one neuropeptide, whose sleep-promoting effects are best documented so far (Obál \& Krueger, 2004;Steiger et al., 1992). GHRH increased nonREM sleep when given by various routes of administration (iv, intracerebroventricular, intrapreoptic) to 
laboratory animals (Ehlers et al., 1986;Obál et al., 1986;1996;Zhang et al., 1999) and (iv, intranasal) to male humans subjects (Steiger et al., 1992;Kerkhofs et al., 1993;Marshall et al., 1996;Perras et al., 1999). Various animal models showed that nonREM sleep is elevated, when the amount of GHRH is high and is decreased when GHRH is low (transgenic animals, GHRH antagonists, GHRH antibodies) (Obál \& Krueger, 2004). GHRH appears to be involved in sleep promotion after sleep deprivation (Obál et al., 1992). In young normal subjects after pulsatile iv administration of GHRH SWS and GH increase, whereas cortisol decreases (Steiger et al., 1992). This effect is in contrast to the decrease of SWS and GH and the increase of cortisol after $\mathrm{CRH}$ in young male healthy volunteers (Holsboer et al., 1988). These observations support the view of a reciprocal interaction of GHRH and $\mathrm{CRH}$ in sleep-endocrine regulation, which was first submitted by Ehlers \& Kupfer (1997). The effect of GHRH appears to depend on gender, age and the time of administration (Steiger, 2007). In women, in contrast to men, sleep was impaired and ACTH and cortisol were elevated after GHRH (Antonijevic et al., 2000a;Antonijevic et al., 2000b). Only a moderate sleep-promoting effect of GHRH was found in healthy elderly subjects as the number of awakenings decreased after the peptide, whereas SWS remained unchanged (Guldner et al., 1997). When GHRH was given during the early morning hours to young normal subjects sleep EEG remained unchanged (Schier et al., 1997).

In addition to GHRH all components of the somatotrophic axis appear to be involved in sleep regulation (Obál \& Krueger, 2004). Therefore it was of high interest to examine the effect of ghrelin on sleep after the substance became available. In a pioneering study Weikel et al. (2003) showed that during the whole night SWS and during the second half of the night its equivalent derived from quantitative EEG analysis, accumulated slow-wave activity (SWA) increased after pulsatile iv ghrelin administration $(4 \times 50 \mu \mathrm{g}$ from 22.00 to 01.00$)$ to healthy young men (see figure 1). REM sleep was reduced during the second third of the night as during the whole night GH and prolactin were stimulated. Cortisol increased during the first half of the night in comparison to placebo (see figure 2). ACTH was elevated by trend only. The effects of ghrelin on sleep EEG and GH secretion resemble the changes seen after GHRH (Steiger et al., 1992), whereas the increase of cortisol after ghrelin is opposite to the decrease of this hormone after GHRH (Steiger et al., 1992) and resembles the 
effects of GHRP-6 (Frieboes et al., 1995) and hexarelin (Frieboes et al., 2004) suggesting that ghrelin may act as an interface between the hypothalamo-pituitary somatotrophic and the hypothalamo-pituitary adrenocortical systems. At the same time as the report by Weikel et al. (2003), Obàl et al. (2003) found an increase of SWS after intraperitoneal ghrelin administration in mice. These authors showed that intact GHRH receptors are the prerequisite of the sleep-promoting action of ghrelin, since this effect was absent in mice with deficient $\mathrm{GHRH}$ receptors.

- Please insert figures 1 and 2 near to here -

Beside of its effects on $\mathrm{GH}$, the hypothalamo-pituitary adrenocorticoal hormones and prolactin, ghrelin influences the sleep related release of more endocrine systems. Intracerebroventricular injection of ghrelin in rats suppressed the pulsatile secretion of hypothalamic luteinizing hormone (LH) releasing hormone and of LH (FernandezFernandez et al., 2005; Furuta et al., 2001). After pulsatile injection of ghrelin in healthy young male subjects lower mean plasma levels of both LH (23.40 until 02.00 h) and testosterone (00.40 to $03.00 \mathrm{~h}$ ) occurred than after placebo. After the first administration of ghrelin LH peak levels were significantly smaller than after placebo (see figure 3). Furthermore the interval between this and the preceeding peak was significantly longer after ghrelin than after placebo. Significantly more LH pulses occurred after placebo than after ghrelin administration (Kluge et al., 2007a). In all, ghrelin caused both a delay and suppression of the amplitude of LH pulses.

\section{- Please insert figure 3 near to here -}

Sleep-related secretion of profiles of follicle stimulating hormone (FSH) were investigated in young healthy male volunteers after $4 \times 50 \mu \mathrm{g}$ ghrelin or placebo given iv between 22.00 and $01.00 \mathrm{~h}$. The FSH plasma levels were significantly lower after ghrelin than after placebo during the interval between 01.00 and $02.20 \mathrm{~h}$ (Kluge et al., 2009b). This study shows, that ghrelin moderately suppresses FSH secretion in young male subjects.

The influence of ghrelin on the hypothalamo-pituitary-thyroid (HPT) axis was studied in animal models and in humans. Ghrelin or placebo was injected 
intracerebroventricularly every 24 hours for five days to rats. After ghrelin pituitary thyroid-stimulating hormone (TSH) cells were smaller and TSH plasma levels were blunted resulting in less active thyroid follicles and thyroxine $\left(T_{4}\right)$ plasma levels (Sosic-Jurjevic et al., 2009). The sleep-associated concentrations of the hormones of the HPT axis were studied in 10 young female and 10 young male healthy volunteers after $4 \times 50 \mu \mathrm{g}$ ghrelin or placebo given hourly between 22.00 and $01.00 \mathrm{~h}$. Ghrelin induced a subtle increase of thyroxin ( $\left.\mathrm{fT}_{4}\right)$ followed by a marked decrease of $\mathrm{TSH}$. This decrease occurred after the physiological TSH surge, which was not affected. The trijodothyronine $\left(\mathrm{fT}_{3}\right.$ ) and thyroid-binding globulin (TBG) were not affected (Kluge et al., 2010b). These findings support the hypothesis that ghrelin suppresses the HPT axis in humans, which counteracts its energy-saving effects.

The effects of ghrelin on sleep in humans are influenced by the time of administration, gender and age. When ghrelin was given in a pulsatile fashion between 04.00 and $07.00 \mathrm{~h}$ during the early morning sleep EEG remained unchanged, whereas $\mathrm{GH}$ and cortisol increased (Kluge et al., 2007c). This finding is similar to the lack of major sleep-EEG changes after GHRH, when given during the same interval to young healthy volunteers (Schier et al., 1997). Whereas after GHRH opposite effects on sleep EEG and nocturnal hormone secretion in women and men were found (Antonijevic et al., 2000a;2000b) sleep EEG remained unchanged in young healthy women after iv ghrelin (Kluge et al., 2007b) in contrast to the sleep-promoting effect in male subjects (Weikel et al., 2003;Kluge et al., 2008). The sexual dimorphism was also found in elderly healthy men and women. SWS, nonREM sleep, GH and cortisol increased and wakefulness decreased in healthy male volunteers, who were 60 years and older. In contrast in women of the same age range sleep EEG remained unchanged (Kluge et al., 2010a). The endocrine effects of ghrelin were similar to those in male subjects, and in young and elderly women as well (Kluge et al., 2007b;2010a). Since sleep-EEG effects were absent in premenopausal and postmenopausal women as well, it is unlikely that estrogens contribute to this sexual dimorphism.

The interaction of ghrelin, GHRH and $\mathrm{CRH}$ in sleep regulation was studied in young male healthy volunteers (Kluge et al., 2008). In this study 10 young male healthy volunteers received in a randomised fashion four bolus injections of placebo (A), 
ghrelin (B), ghrelin + GHRH (C), or ghrelin + CRH (D). In all ghrelin conditions nonREM sleep increased significantly compared to placebo whereas REM sleep decreased. After $\mathrm{CRH}+$ ghrelin the time spent awake and the REM latency (interval between sleep onset and the first occurrence of sleep stage REM) increased compared to other treatment conditions. $\mathrm{CRH}$ enhanced the ghrelin-induced cortisol secretion (see figure 4) but did not affect GH secretion. After GHRH the ghrelininduced GH secretion was elevated, whereas GHRH did not affect cortisol secretion. In conclusion, ghrelin increased nonREM sleep and decreased REM sleep. Ghrelin and $\mathrm{CRH}$ also tended to enhance the effects of ghrelin on sleep. When $\mathrm{CRH}$ was coadministered with ghrelin it promoted sleep, in contrast to its sleep-impairing effect after having been administered alone (Holsboer et al., 1988). Furthermore $\mathrm{CRH}$ decreased REM latency. This finding is in line with the REM sleep-promoting role of this peptide. For example REM sleep is enhanced in $\mathrm{CRH}$-overexpressing mice compared to the wildtype (Kimura et al., 2010).

- Please insert figure 4 near to here -

In a single healthy volunteer we observed that after a bolus injection of $100 \mu \mathrm{g}$ at $22.00 \mathrm{~h}$ the subject developed distinct hunger and claimed for an additional dinner and snacks. After additional injections of $3 \times 100 \mu \mathrm{g}$ ghrelin his sleep was impaired (Weikel et al., 2005). Night eating syndrome is characterized by repetitive awakening because of hunger and excessive eating. In a patient with night-eating syndrome, who was not obese, we observed higher nocturnal ghrelin levels than usually seen in healthy young women (Rosenhagen et al., 2005). These case reports suggest a dose-dependent action of ghrelin during the night. Under physiological conditions sleep is a long period of fasting in healthy humans. Possibly elevated endogenous (Rosenhagen et al., 2005) or exogenous (Weikel et al., 2005) ghrelin levels may disrupt sleep due to increased hunger, whereas after lower dosages (in our experiments $4 \times 50 \mu \mathrm{g}$ ) sleep is promoted in male subjects or remained unchanged in female subjects. Hunger after ghrelin administration may explain the contrasting findings in a series of excellent studies by Szentirmai et al. After intracerebroventricular (Szentirmai et al., 2006) and after intrahypothalamic (Szentirmai et al., 2007) ghrelin administration to the rat wakefulness and feeding increased. In detail intracerebroventricular ghrelin injections at light onset and at dark 
onset suppressed nonREM sleep and REM sleep for two hours in ad libitum-fed rats. This decrease was followed by an increase in nonREM sleep during hours 3-12 after some dosages of ghrelin. In feeding-restricted rats ghrelin suppressed nonREM sleep during hours 1 and 2 and nonREM sleep during hours 3-12 (Szentirmai et al., 2006). Furthermore Szentirmai et al. (2007) examined the sleep and feeding responses to the microinjections of three dosages of ghrelin into hypothalamic sites that are implicated in the release and regulation, such as the lateral hypothalamus, the medial preoptic area and the paraventricular nucleus at dark onset in rats. The microinjections were followed by an increase in wakefulness. At the same time food consumption increased. A decrease of the EEG SWA after injections into the medial preoptic area was followed by an increase. The authors discussed that sleep and feeding are mutually exclusive behaviours and an increase in feeding might result in shortened sleep time. Alternatively, hunger due to ghrelin injections may cause discomfort that could also interfere with sleep. However, the lowest injected dose of ghrelin into the paraventricular nucleus stimulated feeding as strongly as the higher dose, but did not affect sleep. The authors hypothesized that decreased wakefulness and increased feeding are two parallel outputs of the hypothalamic ghrelin-sensitive circuitry. Its activation appears to trigger the behavioural sequence during the first hours of the activity period in rats, the "dark onset syndrome". One may keep in mind a possible delayed sleep-promoting action of ghrelin following the feeding period in some of these experiments.

In another study Szentirmai et al. found that ghrelin knock out mice slept less than the wild type (2007). This study points to a sleep-promoting effect of ghrelin. In a similar vein Schüssler et al. (2005) reported an advanced increase of ghrelin during the recovery night after sleep deprivation (see figure 5). An endogenous substance which accumulates during sleep deprivation is a candidate for a sleep-promoting substance. A similar result derived from a study by Spiegel et al. (Spiegel et al., 2004). These authors compared intraindividually subjects with restricted (four hours per night) and prolonged (10 hours per night) sleep for two days during each condition. At daytime ghrelin levels were higher in the subjects with the restricted sleep condition when compared to the prolonged condition. Furthermore Taheri et al. (2004) reported a correlation between short sleep time and elevated ghrelin levels in a cohort of 1,024 volunteers from the Wisconsin Sleep Cohort Study. During sleep 
deprivation nocturnal ghrelin levels were blunted around sleep onset in comparison to the sleep condition (Dzaja et al., 2004).

\section{- Please insert figure 5 near to here -}

The relationship between sleep, feeding, ghrelin and its antagonist in the energy balance, leptin, in the rat was investigated by Bodosi et al. (2004). Animals underwent three experimental conditions: Free feeding rats with normal diurnal rhythms, rats with feeding restricted to the 12 hours night period and rats subjected to five hours of sleep deprivation at the beginning of the light cycle. Plasma ghrelin and leptin levels showed diurnal rhythms. The ghrelin peak preceded and the leptin peak followed the major daily feeding peak in hour 1 after dark onset. Restricted feeding reversed this rhythm and the rhythm of REM sleep whereas the duration and intensity of nonREM sleep were responsive to restricted feeding. Sleep deprivation stimulated plasma ghrelin and induced feeding, but had no influence on leptin concentrations. After sleep deprivation biphasic elevations in the hypothalamic ghrelin content occurred. The authors concluded that the variations in hypothalamic ghrelin contents might be associated with sleep-wake activity in rats (see figure 6).

\section{- Please insert figure 6 near to here -}

Sleep and thermoregulatory responses to three days of cold exposure to the combined challenge of cold environment temperature and fasting were investigated in preproghrelin knockout mice (originally named ghrelin knockout mice) and in ghrelin receptor knockout mice. It was shown that mice lacking the preproghrelin gene, but not those lacking the ghrelin receptor, have impaired abilities to manifest and integrate normal sleep and thermoregulatory responses to metabolic challenges. In response to fasting at $17^{\circ} \mathrm{C}$ the preproghrelin knockout mice entered hypothermic bouts associated with reduced sleep. Prior to treatment with obestatin, which is like a preproghrelin gene product, attenuated this hypothermic response of the preproghrelin knockout mice (Szentirmai et al., 2009). The authors concluded, that products of the preproghrelin gene regulate physiologic sleep and body temperature responses to metabolic challenge in mice and may be involved in mechanisms of 
adaptation to harsh environmental conditions. The results may also help to better understand the physiology of sustaining energy stores in hibernating species.

Previous studies suggest the occurrence of peaks of ghrelin around sleep onset (Cummings et al., 2001;Dzaja et al., 2004). This issue was not supported in a study with a more frequent sampling of blood specimens (Schüssler et al., 2005). In the latter study a gender difference was found between the onset of the study at 20.00 and $23.00 \mathrm{~h}$. During this period ghrelin levels increased in healthy male subjects. At $23.00 \mathrm{~h}$ a level was reached as found in women from $20.00 \mathrm{~h}$. Until $07.00 \mathrm{~h}$ no major changes in ghrelin levels, particularly no ghrelin peak like the GH peak occurred (see figure 7). A trend suggesting a lower time spent in stage 1 sleep in subjects with high nocturnal ghrelin levels was found. Since sleep stage 1 means shallow sleep, also this finding suggests a sleep-promoting effect of ghrelin.

\section{- Please insert figure 7 near to here -}

Furthermore in male patients with primary insomnia and in a control group ghrelin levels were measured three times during the night (at 23.00, 02.00 and $06.00 \mathrm{~h}$ ). The insomnia patients showed less total sleep time, stage 2 and REM sleep were decreased, sleep efficiency and more stage 1 sleep than the controls. The ghrelin levels across the night were significantly lower in the insomnia patients, whereas leptin levels did not differ between groups (Motivala et al., 2009). Also this observation supports a sleep-promoting influence of ghrelin.

\section{Ghrelin and memory}

A growing number of studies in rodents suggests that ghrelin is involved in memory processes. Intracerebroventricular administration of ghrelin as well as injection of ghrelin in the hippocampus, amygdala and dorsal raphe nucleus dose dependently enhanced memory retention in an avoidance task in rats (Carlini et al., 2002, 2004, 2007) and mice (Diano et al., 2006). Of note, this effect could be observed only if ghrelin was injected before training, but not before retrieval and only for long term memory, i.e. retention times of more than 3 hours (Carlini et al., 2010a). Also object recognition was enhanced by ghrelin administration to the hippocampus in rats (Carlini et al., 2007). Likewise in mice, decreases in object recognition performance 
due to chronic food restriction were counteracted by ghrelin administration (Carlini et al., 2008). Subcutaneous injections of ghrelin or the ghrelin mimetic LY444711 led to a marked improvement in spatial memory retention in mice (Diano et al., 2006). Interestingly, ghrelin receptor deficient mice express impairments in spatial learning, but not avoidance learning compared to wild types (Davis et al., in press). Since ghrelin receptor agonists enhanced memory retention in rats (Atcha et al., 2009), the central ghrelin receptor has been proposed as a drug target for therapeutic approaches to treat diseases affecting cognition (Thomas, 2006; Atcha et al., 2009; Carlini et al., 2010a). Indeed, the administration of ghrelin ameliorated memory impairments in an Alzheimer's disease mouse model (Moon et al., 2010). However, an impairment of memory retention in neonatal chicks after ghrelin administration has also been reported recently (Carvajal et al., 2009).

Data on the effects of ghrelin on human cognition is sparse. In contrast to its memory enhancing effects in rodents, serum ghrelin levels were recently shown to be negatively correlated with declarative memory in elderly adults (Spitznagel et al., 2010). Also on procedural memory consolidation the effects of ghrelin seem to be impairing rather than promoting: Nocturnal administration of ghrelin compared to placebo levelled gains in a sequential motor skill task normally seen after a night of sleep (see figure 8), however this difference slightly failed to be significant (Dresler et al., 2010).

\section{Please insert figure 8 near to here -}

The neuroanatomical network integrating ghrelin into memory functions is not well understood (Olszewski et al., 2008). In mice, circulating ghrelin enters the hippocampus and binds to neurons of the hippocampal formation, promoting dendritic spine synapse formation and generation of longterm potentiation (LTP), while ghrelin-knockout mice have reduced spine density compared to controls (Diano et al., 2006). Ghrelin administration in rats reduced the threshold values to generate LTP in the dentate gyrus and increased the nitric oxide (NO) synthesis via NO synthase (NOS) activation in the hippocampus (Carlini et al., 2010b). Since NOS activity was also shown to be different in trained and untrained animals, it was interpreted as one of the endogenous factors in the hippocampus mediating effects 
of ghrelin on memory (Carlini et al., 2010b). However, also striatal activity is modulated by ghrelin administration in humans (Malik et al., 2008), which might counteract possible beneficial effects of ghrelin on hippocampal contributions to sleep-associated sequential motor skill learning (Albouy et al., 2008).

In conclusion, like its effects on sleep, administration of ghrelin elicits very diverse effects on memory. Before proposals about cognition enhancing drugs targeting the central ghrelin receptor are warrantable, much more research is needed to elucidate the effects of ghrelin and its receptor agonists on human memory.

\section{Ghrelin and depression}

A ghrelin gene polymorphism was found to be associated with depression (Nakashima et al., 2008). The potential role of ghrelin in the development of depressive symptoms was investigated in a series of studies in mice (Lutter et al., 2008). Ghrelin levels were physiologically increased by restricting the food intake of mice with a diet containing $60 \%$ of normal calories for 10 days. Ghrelin levels increased fourfold. In the elevated plus maze and forced swim test the calorierestricted wildtype mice showed robust anxiolytic- and antidepressant-like behaviour in comparison to wildtype mice fed ad libitum. After genetic blockade of ghrelin signalling in GHSR knockout ( $G h r^{-/}$) these anxiolytic- and antidepressant-like effects related to calorie restriction did not occur. It was clarified that differences between the two genotypes are not related to differences in sensory motor coordination, general locomotor activity or body weight. Furthermore mice received a subcutaneous dose of ghrelin that induces distinct feeding. Compared with placebo-injected controls these mice showed significantly less anxiety- and depression-like symptoms in the elevated plus maze and forced swim test. In addition it was tested whether ghrelin signalling regulates depressive symptoms in a mouse model of chronic stress. In the chronic social defeat stress procedure mice underwent repetitive bouts of social defeat by aggressive male mice. These mice showed lasting behavioural changes which were reversible by chronic antidepressant treatment. After a chronic social defeat stress mice had significantly elevated ghrelin levels for at least four weeks.


Whereas body weight after chronic social defeat stress did not differ between Ghsr-mice and the wildtype, food intake was enhanced in the wildtype, but not in the 
knockout mice. The authors concluded that activation of ghrelin signalling due to chronic stress may be a homeostatic adaptation that helps to cope with stress at the expense of increased calorie intake. The antidepressant actions of ghrelin may include activation of hypothalamic orexin-containing neurons. This view is supported by the finding that the antidepressant-like effects of ghrelin in the forced swim test were blocked in mice lacking orexin (Lutter et al., 2008).

In contrast to the work by Lutter et al. (2008) other studies suggest an anxiogenic action of ghrelin. After intraventricular and intraperitoneal administration of ghrelin anxiogenic behaviour was induced in mice (Asakawa et al., 2001). Similarly anxiogenesis by ghrelin in rats was reported (Carlini et al., 2002;Carlini et al., 2004). Another series of studies suggested that ghrelin antisense oligonucleotides given into the lateral ventricle resulted in anxiolytic-like effects in rats as shown by elevated plus maze, black and white and conditioned fear tests. Also antidepressant-like effects in rats were reported as demonstrated by the forced swimming test (Kanehisa et al., 2006).

Major depression is a condition of prolonged stress. Nocturnal ghrelin levels however did not differ between patients with depression and normal controls (Kluge et al., 2009a). After four weeks of antidepressive therapy with mirtazapine nocturnal ghrelin levels decreased in comparison to baseline (Schmid et al., 2006). It is likely that this effect is related to a moderate weight gain rather than to an improvement of psychopathology in this study. A subgroup of healthy volunteers who received after an overnight fast a single iv injection of ghrelin reported elevated mood (Schmid et al., 2005). After pulsatile ghrelin administration to male depressed patients an improvement of mood was found by trend as the score of the Befindlichkeits-Skala decreased (Kluge et al., in press). In contrast in women psychopathology remained unchanged. In the same study changes of sleep EEG and hormone secretion showed a sexual dimorphism. In male patients after ghrelin wakefulness decreased and nonREM sleep increased, whereas in female patients REM sleep was suppressed as the time spent in stage REM decreased and REM latency was prolonged. In both sexes after ghrelin the $\mathrm{GH}$ peak was augmented. Secretion patterns of cortisol differed between depressed men and women. In both sexes cortisol plasma levels were elevated after ghrelin being significantly higher than those 
after placebo during the first half of the night. However only in men cortisol subsequently declined to significantly lower plasma levels in ghrelin-treated than in the placebo condition during the second half of the night. In contrast cortisol levels in women during this interval were similar with both treatments (see figure 9) (Kluge et al., in press).

- Please insert figure 9 near to here -

\section{Ghrelin and other psychiatric and neurologic disorders}

Plasma levels of ghrelin are elevated in comparison to healthy subjects in patients with anorexia nervosa (Otto et al., 2001). In patients with Prader-Willi syndrome ghrelin levels were elevated in comparison to normal controls during $24 \mathrm{~h}$ (Paik et al., 2004). These patients are obese. Elevated ghrelin levels in these patients are in contrast to low ghrelin levels observed regularly in obese patients. Also in a group of patients with night eating syndrome and obesity ghrelin levels during $24 \mathrm{~h}$ were blunted (Allison et al., 2005).

In a sample of patients with epilepsy serum ghrelin levels were measured in single blood samples taken in the morning. Mean ghrelin levels of the patients were significantly higher than in healthy volunteers (Berilgen et al., 2006). The authors discuss that the elevation of ghrelin levels could contribute to the lengthening of nonREM sleep in patients with epilepsy and by this way may play a role in the occurrence of seizures. Furthermore they propose that high levels of ghrelin, by affecting $\mathrm{GH}$ and prolactin secretion may facilitate the occurrence of seizures.

During treatment of patients with schizophrenia with the antipsychotic olanzapine plasma ghrelin levels increased (Murashita et al., 2005). It is likely that the change of ghrelin is related to the weight gain which is frequently observed during treatment with olanzapine.

Ghrelin morning levels were determined in patients with obsessive compulsive disorder, accompanied by major depression or not and in normal controls. No differences between groups were found (Emül et al., 2007). 


\section{Conclusions}

Data reviewed here show that the action of ghrelin includes much more than promotion of feeding or appetite. Ghrelin is involved in sleep-wake regulation. It appears to influence memory and it may play a role in affective and other CNS disorders. Accordingly a better understanding of the effects of ghrelin in the CNS may help to develop new therapies for sleep and psychiatric disorders.

\section{Acknowledgement}

Studies from the authors' laboratory were supported by grants from the Deutsche Forschungsgemeinschaft (DFG Ste 486/5-3 to 5-5). 


\section{Figure legends}

Fig. 1 Effects of ghrelin on delta power activity. Accumulated delta power ( \pm SE) for time in bed (TIB) after injection of $4 \times 50 \mu \mathrm{g}$ of ghrelin compared with placebo $(n \pm 7)$. Grey bar: significant changes after ghrelin administration.

Weikel, J.C., Wichniak, A., Ising, M., Brunner, H., Friess, E., Held, K., Mathias, S., Schmid, D.A., Uhr, M., Steiger, A.: Ghrelin promotes slow-wave sleep in humans. American Journal of Physiology, Endocrinology \& Metabolism 284 (2003) E407-E415 @ American Physiological Society, used with permission.

Fig. 2 Time course of nocturnal plasma hormone concentrations of growth hormone $(\mathrm{GH})$ and cortisol (means $\pm \mathrm{SE}$ ) after iv injection of $4 \times 50 \mu \mathrm{g}$ of ghrelin compared with placebo $(n=7)$. Arrows: times of injections.

Weikel, J.C., Wichniak, A., Ising, M., Brunner, H., Friess, E., Held, K., Mathias, S., Schmid, D.A., Uhr, M., Steiger, A.: Ghrelin promotes slow-wave sleep in humans. American Journal of Physiology, Endocrinology \& Metabolism 284 (2003) E407-E415 @ American Physiological Society, used with permission.

Fig. 3 Exemplary nocturnal LH secretion profiles of a healthy man receiving ghrelin or placebo. *, LH pulse.

Fig. 2 from Kluge M. et al. Ghrelin suppresses secretion of luteinizing hormone in humans. Journal of Clinical Endocrinology \& Metabolism 92 (2007) 3202-3205. Copyright 2007, The Endocrine Society.

Fig. 4 Secretion profiles of cortisol in 10 healthy males receiving ghrelin, ghrelin+GHRH, ghrelin+CRH, or placebo (mean \pm SEM).

Tests with contrasts following a Bonferroni-adjusted multivariate ANOVA were used for identifying statistical differences between treatment groups. Cortisol levels significantly differed between 22:20 and 04:00 $\mathrm{h}$ and at 06:20 $\mathrm{h}$. At all these points in time, cortisol levels in the ghrelin+CRH condition were statistically significant different from those in the other conditions. In addition, cortisol levels were statistically significant different in the placebo condition compared to those in the ghrelin (22:2002:20 h) and in the ghrelin+GHRH condition (22:20-02:40 h). \%significant difference compared to ghrelin (po0.05).

Reprinted from Psychoneuroendocrinology, 33, Kluge, M., Schüssler, P. Bleninger, P., Kleyer, S., Uhr, M., Weikel, J.C., Yassouridis, A., Zuber, V., Steiger, A., Ghrelin alone or co-administered with GHRH or $\mathrm{CRH}$ increases non-REM sleep and decreases REM sleep in young males, 497-506, 2008, with permission from Elsevier. 
Fig. 5 Nocturnal ghrelin secretion (mean \pm standard error) at baseline and after sleep deprivation.

Reprinted from Psychoneuroendocrinology, 31, Schüssler, P., Uhr, M., Ising, M., Weikel, J.C., Schmid, D.A., Held, K., Mathias, S., Steiger, A., Nocturnal ghrelin, ACTH, GH and cortisol secretion after sleep deprivation in humans, 915-923, 2006, with permission from Elsevier.

Fig. 6 Diurnal rhythms (hourly mean \pm SE) of time spent in non-rapid eye movement sleep (NREMS), and feeding activity were determined on 3 days and averaged for 24 $\mathrm{h}$ in 51 rats. Diurnal rhythms of plasma (PL) leptin (Lep) and ghrelin (Ghre) concentrations, and hypothalamic (HY) ghrelin contents were determined on day 4 of recording in groups of rats $(n=7-10)$ killed at 4-h intervals. The $24-h$ curves are double-plotted to promote visualization of the rhythms. Time 0 , light onset. Gray columns, dark period. \%Rec time, \%recording time.

B. Bodosi, J. Gardi, I. Hajdu, E. Szentirmai, F. Obal, Jr. and J. M. Krueger: Rhythms of ghrelin, leptin, and sleep in rats: effects of the normal diurnal cycle, restricted feeding, and sleep deprivation. American Journal of Physiology - Regulatory, Integrative \& Comparative Physiology 287:1071-1079, 2004 ๑ American Physiological Society, used with permission.

Fig. 7 Nocturnal ghrelin secretion in male and female subjects.

Means and standard errors of the mean (SEM) are presented. ACTH levels were not determined in samples collected before lights were switched off (23:00 hours). Journal of Sleep Research, 14, Schüssler, P., Uhr, M., Ising, M., Schmid, D., Weikel, J., Steiger A., Nocturnal ghrelin levels - relationship to sleep EEG, the levels of growth hormone, ACTH and cortisol and gender differences, 329-336, 2005, with permission from Wiley.

Fig. 8 Nocturnal administration of ghrelin does not promote memory consolidation in humans.

Mean overnight increases in and standard errors of the mean (SEM) a sequential motor memory task are presented.

Pharmacopsychiatry 43: 277-278, Dresler M, Kluge M, Genzel L, Schüssler P, Steiger A.: Nocturnal administration of ghrelin does not promote memory consolidation. 2010 C Georg Thieme Verlag, used with permission.

Fig. 9 Cortisol secretion profiles in 7 women (A) and 7 men (B) with major depression receiving ghrelin or placebo (mean \pm SEM). *Significant difference compared to placebo $(p<0.05)$. 
Reprinted from Journal of Psychiatric Research, in press, Kluge, M., Schüssler, P., Dresler, M., Schmidt, D., Yassouridis, A., Uhr, M., Steiger, A., Effects of ghrelin on psychopathology, sleep and secretion of cortisol and growth hormone in patients with major depression, (2 October 2010), with permission from Elsevier. 


\section{References}

Allison, K.C., Ahima, R.S., O'Reardon, J.P., Dinges, D.F., Sharma, V., Cummings, D.E., Heo, M., Martino, N.S., Stunkard, A.J., 2005. Neuroendocrine profiles associated with energy intake, sleep, and stress in the night eating syndrome. J. Clin. Endocrinol. Metab 90, 6214-6217.

American Academy of Sleep Medicine, Iber, C., Anoli-Israel, S., Chesson, A., Quan, S.F., 2007. The AASM manual for the scoring of sleep and associated events: Rules, terminology and technical specifications. American Academy of Sleep Medicine, Westchester, Illinois.

Antonijevic, I.A., Murck, H., Frieboes, R.M., Barthelmes, J., Steiger, A., 2000a. Sexually dimorphic effects of GHRH on sleep-endocrine activity in patients with depression and normal controls - part I: the sleep EEG. Sleep Res. Online 3, 5-13. Antonijevic, I.A., Murck, H., Frieboes, R.M., Steiger, A., 2000b. Sexually dimorphic effects of GHRH on sleep-endocrine activity in patients with depression and normal controls - part II: hormone secretion. Sleep Res. Online 3, 15-21.

Asakawa, A., Inui, A., Kaga, T., Yuzuriha, H., Nagata, T., Fujimiya, M., Katsuura, G., Makino, S., Fujino, M.A., Kasuga, M., 2001. A role of ghrelin in neuroendocrine and behavioral responses to stress in mice. Neuroendocrinology 74, 143-147.

Albouy G, Sterpenich V, Balteau E, Vandewalle G, Desseilles M, Dang-Vu T, Darsaud A, Ruby P, Luppi PH, Degueldre C, Peigneux P, Luxen A, Maquet P (2008) Both the hippocampus and striatum are involved in consolidation of motor sequence memory. Neuron 58: 261-272

Atcha Z, Chen WS, Ong AB, Wong FK, Neo A, Browne ER, Witherington J, Pemberton DJ (2009) Cognitive enhancing effects of ghrelin receptor agonists. Psychopharmacology 206: 415-427

Berilgen, M.S., Mungen, B., Ustundag, B., Demir, C., 2006. Serum ghrelin levels are enhanced in patients with epilepsy. Seizure 15, 106-111.

Bodosi, B., Gardi, J., Hajdu, I., Szentirmai, E., Obál, F.Jr., Krueger, J.M., 2004. Rhythms of ghrelin, leptin, and sleep in rats: effects of the normal diurnal cycle, restricted feeding, and sleep deprivation. Am. J. Physiol. Regul. Integr. Comp. Physiol. 287, R1071-R1079. 
Borbély, A.A., 1982. A two process model of sleep regulation. Hum. Neurobiol. 1, 195-204.

Carlini, V.P., Monzon, M.E., Varas, M.M., Cragnolini, A.B., Schioth, H.B., Scimonelli, T.N., de Barioglio, S.R., 2002. Ghrelin increases anxiety-like behavior and memory retention in rats. Biochem. Biophys. Res. Commun. 299, 739-743.

Carlini, V.P., Varas, M.M., Cragnolini, A.B., Schioth, H.B., Scimonelli, T.N., de Barioglio, S.R., 2004. Differential role of the hippocampus, amygdala, and dorsal raphe nucleus in regulating feeding, memory, and anxiety-like behavioral responses to ghrelin. Biochem. Biophys. Res. Commun. 313, 635-641.

Carlini VP, Martini AC, Schioth HB, Ruiz RD, Fiol de Cuneo M, de Barioglio SR (2008) Decreased memory for novel object recognition in chronically food-restricted mice is reversed by acute ghrelin administration. Neuroscience 153:929-934

Carlini, V., Ghersi, M., Schiöth, H.B., de Barioglio, S.R., 2010a. Ghrelin and memory: Differential effects on acquisition and retrieval. Peptides 31, 1190-1193.

Carlini, V., Perez, M.F., Salde, E., Schiöth, H.B., Ramirez, O.A., de Barioglio S.R., 2010b. Ghrelin induced memory facilitation implicates nitric oxide synthase activation and decrease in the threshold to promote LTP in hippocampal dentate gyrus. Physiol. Behav. 101, 117-123.

Carvajal P, Carlini VP, Schiöth HB, de Barioglio S, Salvatierra NA (2009) Central ghrelin increases anxiety in the Open Field test and impairs retention memory in a passive avoidance task in neonatal chicks. Neurobiol. Learn. Mem. 91: 402-407

Copinschi, G., Leproult, R., Van Onderbergen, A., Caufriez, A., Cole, K.Y., Schilling, L.M., Mendel, C.M., De Lepeleire, I., Bolognese, J.A., Van Cauter, E., 1997. Prolonged oral treatment with MK-677, a novel growth hormone secretagogue, improves sleep quality in man. Neuroendocrinology 66, 278-286.

Cummings, D.E., Purnell, J.Q., Frayo, R.S., Schmidova, K., Wisse, B.E., Weigle, D.S., 2001. A preprandial rise in plasma ghrelin levels suggests a role in meal initiation in humans. Diabetes 50, 1714-1719.

Davis J.F., Choi, D.L., Clegg, D.J., Benoit, S.C. Signaling through the ghrelin receptor modulates hippocampal function and meal anticipation in mice. Physiol. Behav. (in press). 
Diano S, Farr SA, Benoit SC, McNay EC, da Silva I, Horvath B, Gaskin FS, Nonaka N, Jaeger LB, Banks WA, Morley JE, Pinto S, Sherwin RS, Xu L, Yamada KA, Sleeman MW, Tschop MH, Horvath TL, 2006. Ghrelin controls hippocampal spine synapse density and memory performance. Nat. Neurosci. 9:381-388

Dresler, M., Kluge, M., Genzel, L., Schüssler, P., Steiger, A., 2010. Nocturnal administration of ghrelin does not promote memory consolidation.

Pharmacopsychiatry 43, 277-278.

Dzaja, A., Dalal, M.A., Himmerich, H., Uhr, M., Pollmächer, T., Schuld, A., 2004. Sleep enhances nocturnal plasma ghrelin levels in healthy subjects. Am. J. Physiol. Endocrinol. Metab. 286, E963-E967.

Ehlers, C.L., Kupfer, D.J., 1997. Slow-wave sleep: do young adult men and women age differently? J. Sleep Res. 6, 211-215.

Ehlers, C.L., Reed, T.K., Henriksen, S.J., 1986. Effects of corticotropin-releasing factor and growth hormone- releasing factor on sleep and activity in rats.

Neuroendocrinology 42, 467-474.

Emül, H.M., Serteser, M., Kurt, E., Ozbulut, O., Guler, O., Gecici, O., 2007. Ghrelin and leptin levels in patients with obsessive-compulsive disorder. Prog.

Neuropsychopharmacol. Biol. Psychiatry 31, 1270-1274.

Fernandez-Fernandez, R., Tena-Sempere, M., Navarro, V.M., Barreiro, M.L., Castellano, J.M., Aguilar, E., Pinilla, L., 2005. Effects of ghrelin upon gonadotropinreleasing hormone and gonadotropin secretion in adult female rats: in vivo and in vitro studies. Neuroendocrinology 82, 245-255.

Frieboes, R.M., Murck, H., Maier, P., Schier, T., Holsboer, F., Steiger, A., 1995. Growth hormone-releasing peptide-6 stimulates sleep, growth hormone, ACTH and cortisol release in normal man. Neuroendocrinology 61, 584-589.

Frieboes, R.M., Murck, H., Antonijevic, I.A., Steiger, A., 1999. Effects of growth hormone-releasing peptide- 6 on the nocturnal secretion of $\mathrm{GH}, \mathrm{ACTH}$ and cortisol and on the sleep EEG in man: role of routes of administration. J. Neuroendocrinol. 11, 473-478.

Frieboes, R.M., Antonijevic, I.A., Held, K., Murck, H., Pollmächer, T., Uhr, M., Steiger, A., 2004. Hexarelin decreases slow-wave sleep and stimulates the sleep-related 
secretion of $\mathrm{GH}, \mathrm{ACTH}$, cortisol and prolactin during sleep in healthy volunteers. Psychoneuroendocrinology 29, 851-860.

Furuta, M., Funabashi, T., Kimura, F., 2001. Intracerebroventricular administration of ghrelin rapidly suppresses pulsatile luteinizing hormone secretion in ovariectomized rats. Biochem. Biophys. Res. Commun. 288, 780-785.

Guldner, J., Schier, T., Friess, E., Colla, M., Holsboer, F., Steiger, A., 1997. Reduced efficacy of growth hormone-releasing hormone in modulating sleep endocrine activity in the elderly. Neurobiol. Aging 18, 491-495.

Holsboer, F., von Bardeleben, U., Steiger, A., 1988. Effects of intravenous corticotropin-releasing hormone upon sleep-related growth hormone surge and sleep EEG in man. Neuroendocrinology 48, 32-38.

Kanehisa, M., Akiyoshi, J., Kitaichi, T., Matsushita, H., Tanaka, E., Kodama, K., Hanada, H., Isogawa, K., 2006. Administration of antisense DNA for ghrelin causes an antidepressant and anxiolytic response in rats. Prog. Neuropsychopharmacol. Biol. Psychiatry 30, 1403-1407.

Kerkhofs, M., Van Cauter, E., Van Onderbergen, A., Caufriez, A., Thorner, M.O., Copinschi, G., 1993. Sleep-promoting effects of growth hormone-releasing hormone in normal men. Am. J. Physiol. Endocrinol. Metab. 264, E594-E598.

Kimura, M., Müller-Preuss, P., Lu, A., Wiesner, E., Flachskamm, C., Wurst, W., Holsboer, F., Deussing, J.M., 2010. Conditional corticotropin-releasing hormone overexpression in the mouse forebrain enhances rapid eye movement sleep. Mol. Psychiatr. 15, 154-165.

Kluge, M., Schüssler, P., Uhr, M., Yassouridis, A., Steiger, A., 2007a. Ghrelin suppresses secretion of luteinizing hormone in humans. J. Clin. Endocrinol. Metab. 92, 3202-3205.

Kluge, M., Schüssler, P., Zuber, V., Kleyer, S., Yassouridis, A., Dresler, M., Uhr, M., Steiger, A., 2007b. Ghrelin enhances the nocturnal secretion of cortisol and growth hormone in young females without influencing sleep. Psychoneuroendocrinology 32 , 1079-1085.

Kluge, M., Schüssler, P., Zuber, V., Yassouridis, A., Steiger, A., 2007c. Ghrelin administered in the early morning increases secretion of cortisol and growth hormone without affecting sleep. Psychoneuroendocrinology 32, 287-292. 
Kluge, M., Schüssler, P., Bleninger, P., Kleyer, S., Uhr, M., Weikel, J.C., Yassouridis, A., Zuber, V., Steiger, A., 2008. Ghrelin alone or co-administered with GHRH or $\mathrm{CRH}$ increases non-REM sleep and decreases REM sleep in young males.

Psychoneuroendocrinology 33, 497-506.

Kluge, M., Schüssler, P., Schmid, D., Uhr, M., Kleyer, S., Yassouridis, A., Steiger, A., 2009a. Ghrelin plasma levels are not altered in major depression.

Neuropsychobiology 59, 199-204.

Kluge, M., Uhr, M., Bleninger, P., Yassouridis, A., Steiger, A., 2009b. Ghrelin suppresses secretion of FSH in males. Clin. Endocrinol. 70, 920-923.

Kluge, M., Gazea, M., Schüssler, P., Genzel, L., Dresler, M., Kleyer, S., Uhr, M., Yassouridis, A., Steiger, A., 2010a. Ghrelin increases slow wave sleep and stage 2 sleep and decreases stage 1 sleep and REM sleep in elderly men but does not affect sleep in elderly women. Psychoneuroendocrinology 35, 297-304.

Kluge, M., Riedl, S., Uhr, M., Schmidt, D., Zhang, X., Yassouridis, A., Steiger, A., 2010b. Ghrelin affects the hypothalamus-pituitary-thyroid axis in humans by increasing free thyroxine and decreasing TSH in plasma. Eur. J. Endocrinol. 162, 1059-1065.

Kluge, M., Schüssler, P., Dresler, M., Schmidt, D., Yassouridis, A., Uhr, M., Steiger, A. Effects of ghrelin on psychopathology, sleep and secretion of cortisol and growth hormone in patients with major depression. J. Psychiatr. Res., in press.

Kojima, M., Hosoda, H., Date, Y., Nakazato, M., Matsuo, H., Kangawa, K., 1999.

Ghrelin is a growth hormone-releasing acylated peptide from stomach. Nature 402, 656-660.

Krueger, J.M., Majde, J.A., Rector, D.M., 2011. Cytokines in immune function and sleep regulation, in: Montagna, P., Chokroverty, S. (Eds.), Handbook of Clinical Neurology. Elsevier B.V., Amsterdam, pp. 229-240.

Luppi, P.H., Fort, P., 2011. Neurochemistry of sleep: an overview of animal experimental work, in: Montagna, P., Chokroverty, S. (Eds.), Handbook of Clinical Neurology. Elsevier B.V., Amsterdam, pp. 173-190.

Lutter, M., Sakata, I., Osborne-Lawrence, S., Rovinsky, S.A., Anderson, J.G., Jung, S., Birnbaum, S., Yanagisawa, M., Elmquist, J.K., Nestler, E.J., Zigman, J.M., 2008. 
The orexigenic hormone ghrelin defends against depressive symptoms of chronic stress. Nat. Neurosci. 11, 752-753.

Malik S, McGlone F, Bedrossian D, Dagher A (2008) Ghrelin modulates brain activity in areas that control appetitive behavior. Cell Metab. 7: 400-409.

Marshall, L., Mölle, M., Böschen, G., Steiger, A., Fehm, H.L., Born, J., 1996. Greater efficacy of episodic than continuous growth hormone releasing hormone (GHRH) administration in promoting slow wave sleep (SWS). J. Clin. Endocrinol. Metab. 81, 1009-1013.

Moon M., Choi, J.G., Nam, D.W., Hong, H.S., Choi, Y.J., Oh, M.S., Mook-Jung, I., 2010. Ghrelin ameliorates cognitive dysfunction and neurodegeneration in intrahippocampal amyloid- $\beta$ 1-42 oligomer-injected mice. J. Alzheimers Dis. 23, 1-13. Moreno-Reyes, R., Kerkhofs, M., L'Hermite-Balériaux, M., Thorner, M.O., Van Cauter, E., Copinschi, G., 1998. Evidence against a role for the growth hormone-releasing peptide axis in human slow-wave sleep regulation. Am. J. Physiol. Endocrinol. Metab. 274, E779-E784.

Motivala, S.J., Tomiyama, A.J., Ziegler, M., Khandrika, S., Irwin, M.R., 2009. Nocturnal levels of ghrelin and leptin and sleep in chronic insomnia.

Psychoneuroendocrinology 34, 540-545.

Murashita, M., Kusumi, I., Inoue, T., Takahashi, Y., Hosoda, H., Kangawa, K., Koyama, T., 2005. Olanzapine increases plasma ghrelin level in patients with schizophrenia. Psychoneuroendocrinology 30, 106-110.

Nakashima, K., Akiyoshi, J., Hatano, K., Hanada, H., Tanaka, Y., Tsuru, J., Matsushita, H., Kodama, K., Isogawa, K., 2008. Ghrelin gene polymorphism is associated with depression, but not panic disorder. Psychiatr. Genet. 18, 257.

Obál, F.Jr., Sary, G., Alföldi, P., Rubicsek, G., 1986. Vasoactive intestinal polypeptide promotes sleep without effects on brain temperature in rats at night. Neurosci. Lett. 64, 236-240.

Obál, F.Jr., Payne, L., Opp, M., Alföldi, P., Kapás, L., Krueger, J.M., 1992. Growth hormone-releasing hormone antibodies suppress sleep and prevent enhancement of sleep after sleep deprivation. Am. J. Physiol. Regul. Integr. Comp. Physiol. 263, R1078-R1085. 
Obál, F.Jr., Floyd, R., Kapás, L., Bodosi, B., Krueger, J.M., 1996. Effects of systemic $\mathrm{GHRH}$ on sleep in intact and in hypophysectomized rats. Am. J. Physiol. Endocrinol. Metab. 270, E230-E237.

Obál, F.Jr., Alt, J., Taishi, P., Gardi, J., Krueger, J.M., 2003. Sleep in mice with nonfunctional growth hormone-releasing hormone receptors. Am. J. Physiol. Regul. Integr. Comp. Physiol. 284, R131-R139.

Obál, F.Jr., Krueger, J.M., 2004. GHRH and sleep. Sleep Medicine Rev. 8, 367-377. Otto, B., Cuntz, U., Fruehauf, E., Wawarta, R., Folwaczny, C., Riepl, R.L., Heiman, M.L., Lehnert, P., Fichter, M., Tschöp, M., 2001. Weight gain decreases elevated plasma ghrelin concentrations of patients with anorexia nervosa. Eur. J. Endocrinol. 145, R5-R9.

Paik, K.H., Jin, D.K., Song, S.Y., Lee, J.E., Ko, S.H., Song, S.M., Kim, J.S., Oh, Y.J., Kim, S.W., Lee, S.H., Kim, S.H., Kwon, E.K., Choe, Y.H., 2004. Correlation between fasting plasma ghrelin levels and age, body mass index (BMI), BMI percentiles, and 24-hour plasma ghrelin profiles in Prader-Willi syndrome. J. Clin. Endocrinol. Metab 89, 3885-3889.

Perras, B., Marshall, L., Köhler, G., Born, J., Fehm, H.L., 1999. Sleep and endocrine changes after intranasal administration of growth hormone-releasing hormone in young and aged humans. Psychoneuroendocrinology 24, 743-757.

Rechtschaffen, A., Kales, A., 1968. A Manual of Standardized Terminology, Techniques and Scoring System for Sleep Stages of Human Subjects. US Department of Health, Education \& Welfare, Neurological Information Network, Bethesda, MD.

Rosenhagen, M.C., Uhr, M., Schüssler, P., Steiger, A., 2005. Elevated plasma ghrelin levels in night-eating syndrome. Am. J. Psychiatry 162, 813.

Schier, T., Guldner, J., Colla, M., Holsboer, F., Steiger, A., 1997. Changes in sleependocrine activity after growth hormone-releasing hormone depend on time of administration. J. Neuroendocrinol. 9, 201-205.

Schmid, D.A., Held, K., Ising, M., Uhr, M., Weikel, J.C., Steiger, A., 2005. Ghrelin stimulates appetite, imagination of food, $\mathrm{GH}, \mathrm{ACTH}$ and cortisol, but does not affect leptin in normal controls. Neuropsychopharmacology 30, 1187-1192. 
Schmid, D.A., Wichniak, A., Uhr, M., Ising, M., Brunner, H., Held, K., Weikel, J., Sonntag, A., Steiger, A., 2006. Changes of sleep architecture, spectral composition of sleep EEG, the nocturnal secretion of cortisol, $\mathrm{ACTH}, \mathrm{GH}$, prolactin, melatonin, ghrelin and leptin and the DEX-CRH test in depressed patients during treatment with mirtazapine. Neuropsychopharmacology 31, 832-844.

Schüssler, P., Uhr, M., Ising, M., Schmid, D., Weikel, J., Steiger, A., 2005. Nocturnal ghrelin levels - relationship to sleep EEG, the levels of growth hormone, ACTH and cortisol - and gender differences. J. Sleep Res. 14, 329-336.

Sosic-Jurjevic, B., Stevanovic, D., Milosevic, V., Sekulic, M., Starcevic, V., 2009. Central ghrelin affects pituitary-thyroid axis: histomorphological and hormonal study in rats. Neuroendocrinology 89, 327-336.

Spiegel, K., Tasali, E., Penev, P., Van Cauter, E., 2004. Brief communication: Sleep curtailment in healthy young men is associated with decreased leptin levels, elevated ghrelin levels, and increased hunger and appetite. Ann. Intern. Med. 141, 846-850. Spitznagel, M.B., Benitez, A., Updegraff, J., Potter, V., Alexander, T., Glickman, E., Gunstadt, J., 2010. Serum ghrelin is inversely associated with cognitive function in a sample of non-demented elderly. Psychiatry Clin. Neurosci. 64, 608-611.

Steiger, A., Guldner, J., Hemmeter, U., Rothe, B., Wiedemann, K., Holsboer, F., 1992. Effects of growth hormone-releasing hormone and somatostatin on sleep EEG and nocturnal hormone secretion in male controls. Neuroendocrinology 56, 566-573.

Steiger, A., 2007. Neurochemical regulation of sleep. J. Psychiatr. Res. 41, 537-552.

Szentirmai, E., Hajdu, I., Obál, F.Jr., Krueger, J.M., 2006. Ghrelin-induced sleep responses in ad libitum fed and food-restricted rats. Brain Res. 1088, 131-140.

Szentirmai, E., Kapás, L., Krueger, J.M., 2007. Ghrelin microinjection into forebrain sites induces wakefulness and feeding in rats. Am. J. Physiol. Regul. Integr. Comp. Physiol. 292, R575-R585.

Szentirmai, E., Kapás, L., Sun, Y., Smith, R.G., Krueger, J.M., 2009. The preproghrelin gene is required for the normal integration of thermoregulation and sleep in mice. Proc. Natl. Acad. Sci. U. S A 106, 14069-14074. 
Taheri, S., Lin, L., Austin, D., Young, T., Mignot, E., 2004. Short sleep duration is associated with reduced leptin, elevated ghrelin, and increased body mass index. PLoS Med. 1, e62.

Tschöp, M., Smiley, D.L., Heiman, M.L., 2000. Ghrelin induces adiposity in rodents. Nature 407, 908-913.

Weikel, J.C., Wichniak, A., Ising, M., Brunner, H., Friess, E., Held, K., Mathias, S., Schmid, D.A., Uhr, M., Steiger, A., 2003. Ghrelin promotes slow-wave sleep in humans. Am. J. Physiol. Endocrinol. Metab. 284, E407-E415.

Weikel, J., Held, K., Schmid, D.A., Uhr, M., Steiger, A., 2005. Single case report: 100 $\mu \mathrm{g}$ ghrelin at 22:00 increases distinctly hunger, food intake and nocturnal plasma levels of GH, ACTH and cortisol in a young man - evidence for dose-dependent effects of ghrelin on appetite? Pharmacopsychiatry 38, 284.

Wren, A.M., Small, C.J., Ward, H.L., Murphy, K.G., Dakin, C.L., Taheri, S., Kennedy, A.R., Roberts, G.H., Morgan, D.G.A., Ghatei, M.A., Bloom, S.R., 2000. The novel hypothalamic peptide ghrelin stimulates food intake and growth hormone secretion. Endocrinology 141, 4325-4328.

Wren, A.M., Seal, L.J., Cohen, M.A., Brynes, A.E., Frost, G.S., Murphy, K.G., Dhillo, W.S., Ghatei, M.A., Bloom, S.R., 2001. Ghrelin enhances appetite and increases food intake in humans. J. Clin. Endocrinol. Metab. 86, 5992-5995.

Zhang, J., Obál, F.Jr., Zheng, T., Fang, J., Taishi, P., Krueger, J.M., 1999. Intrapreoptic microinjection of GHRH or its antagonist alters sleep in rats. J. Neurosci. 19, 2187-2194. 


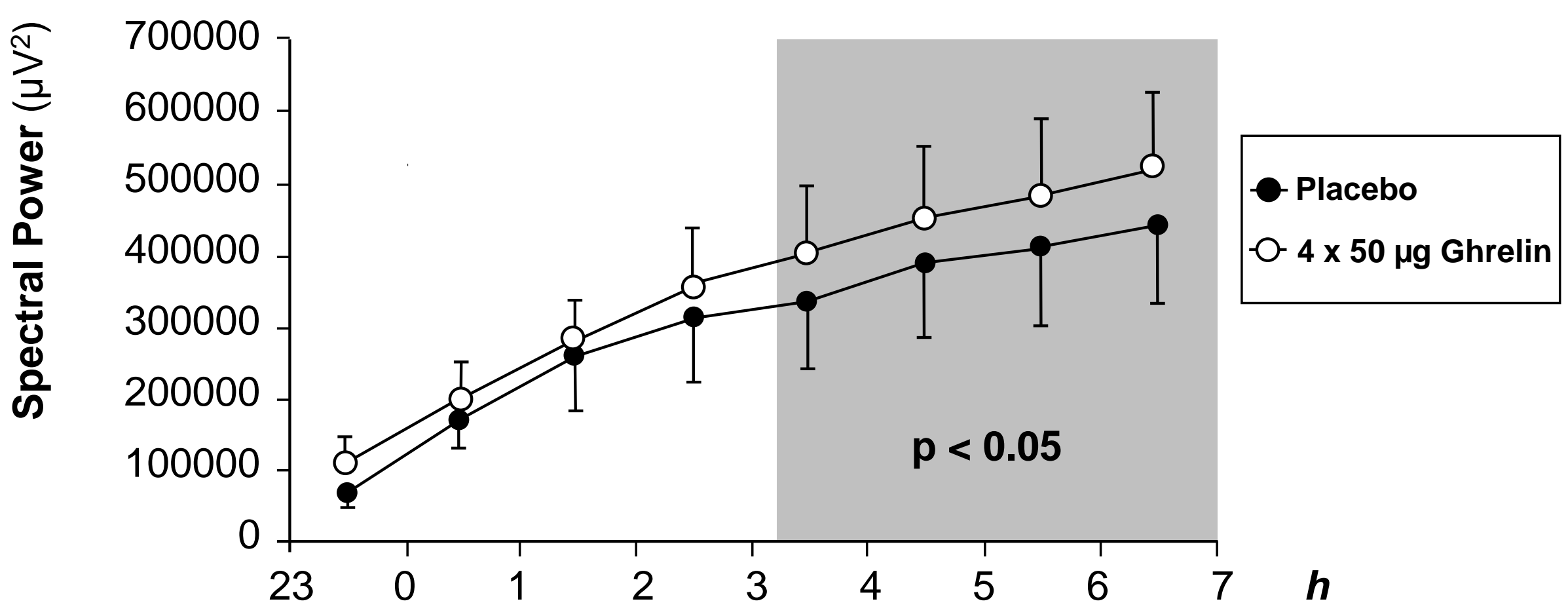


iripure 2



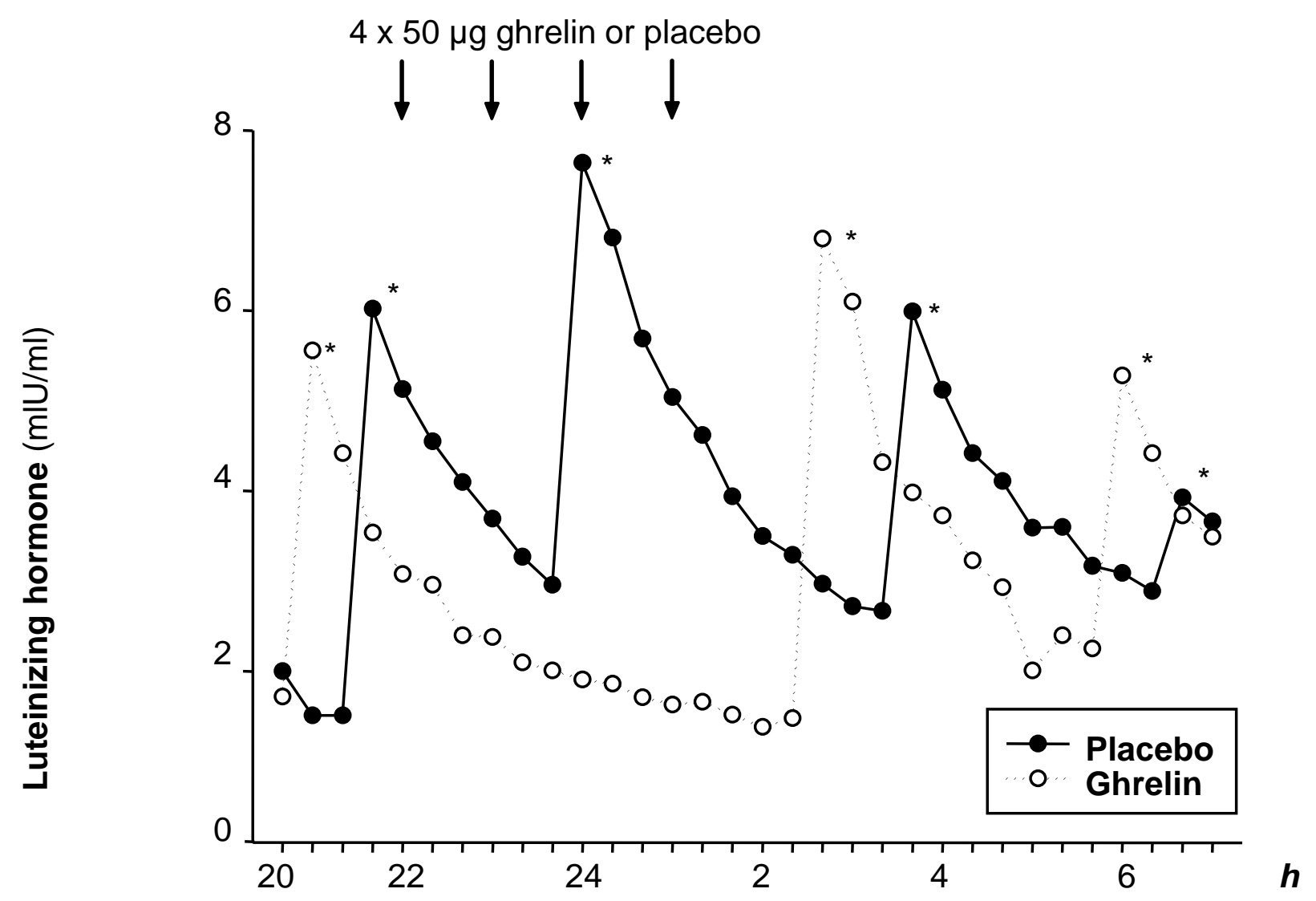




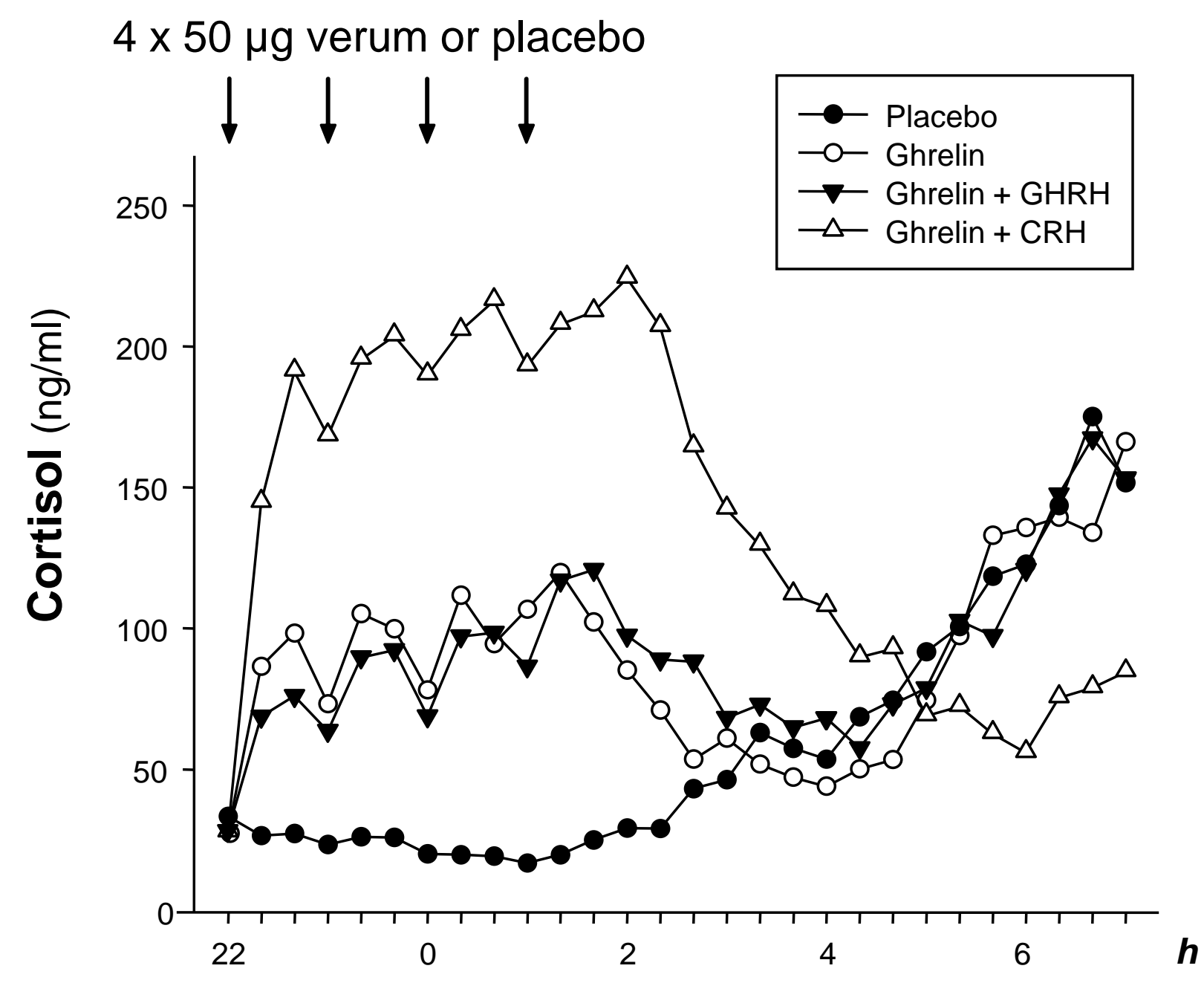




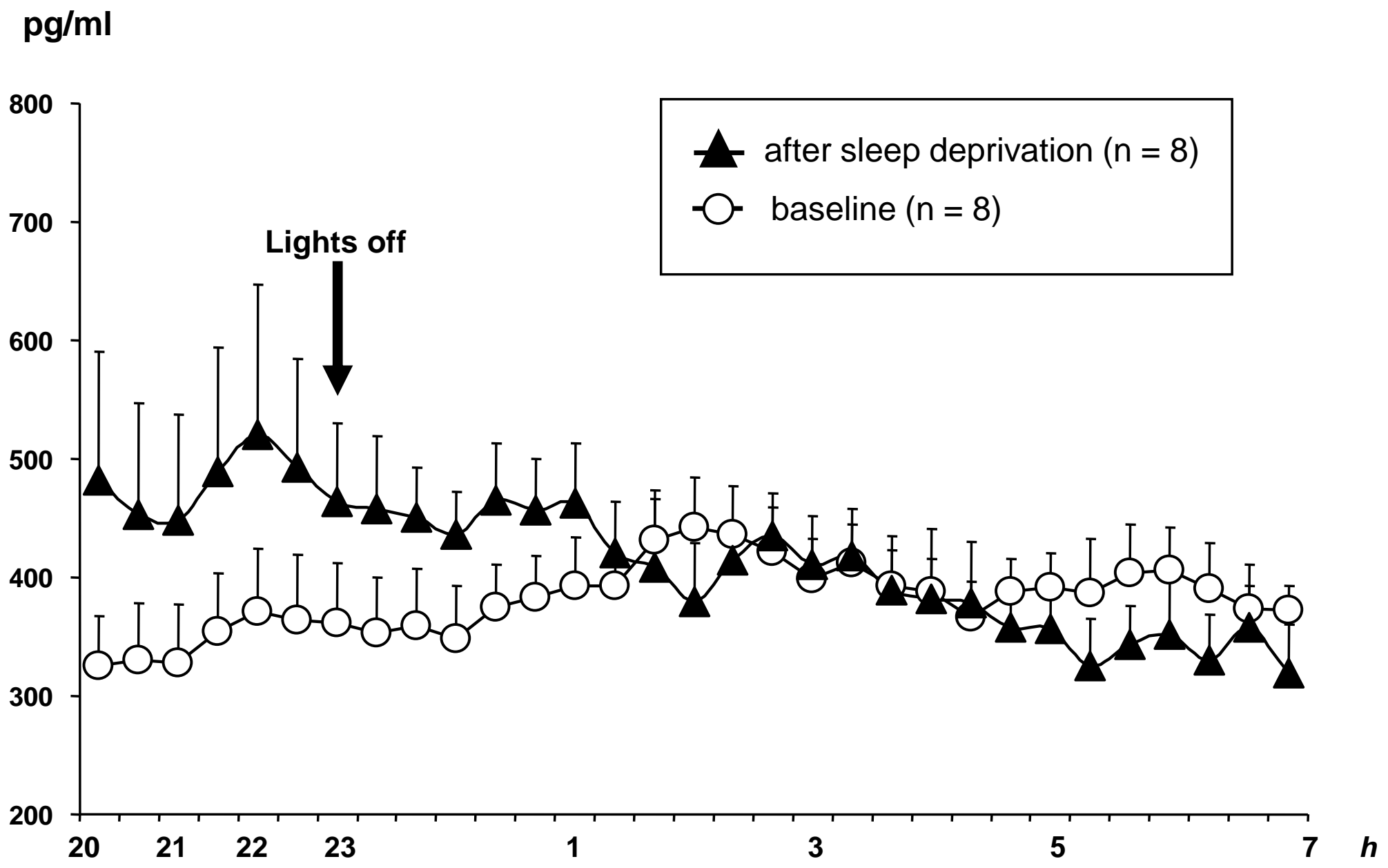



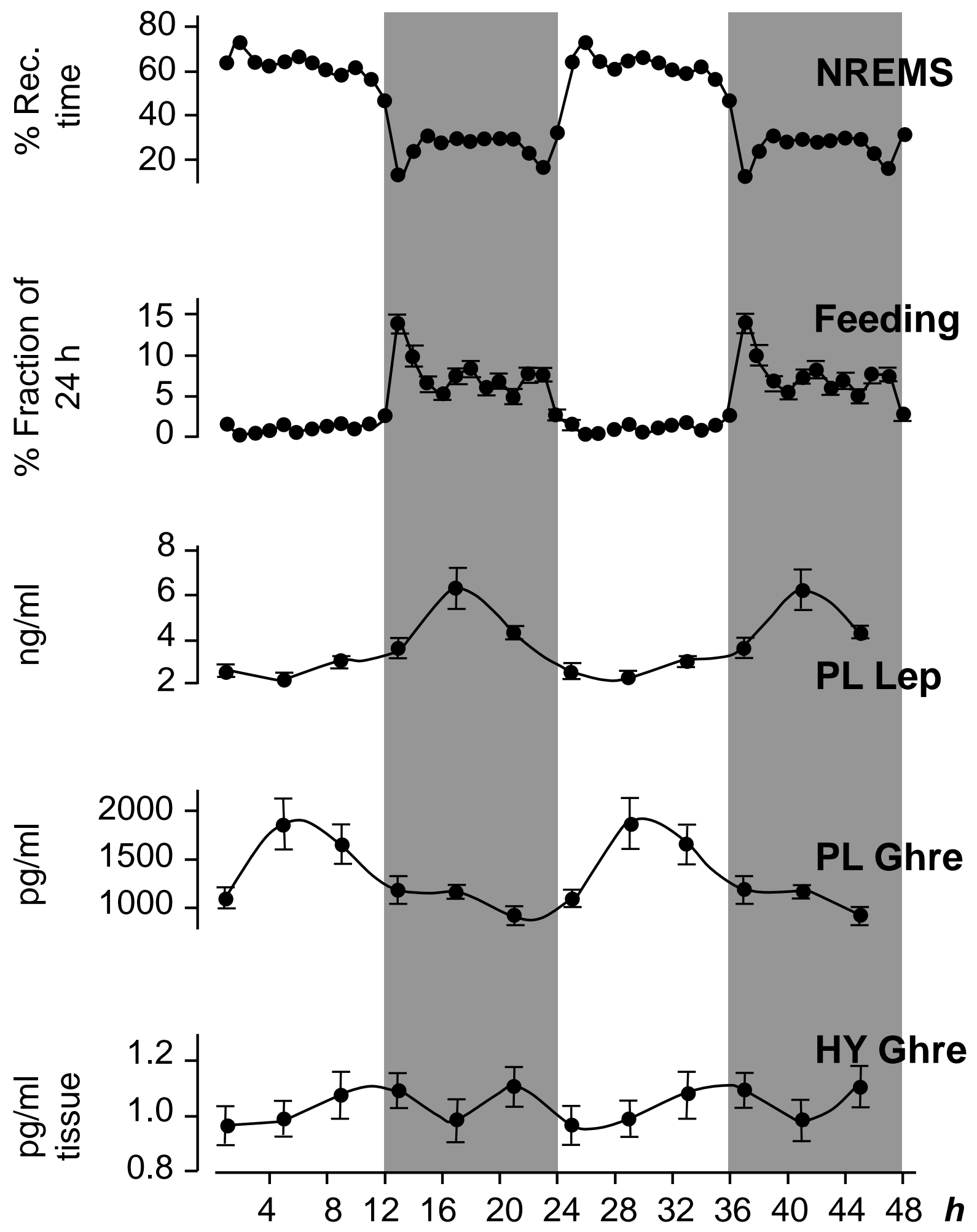


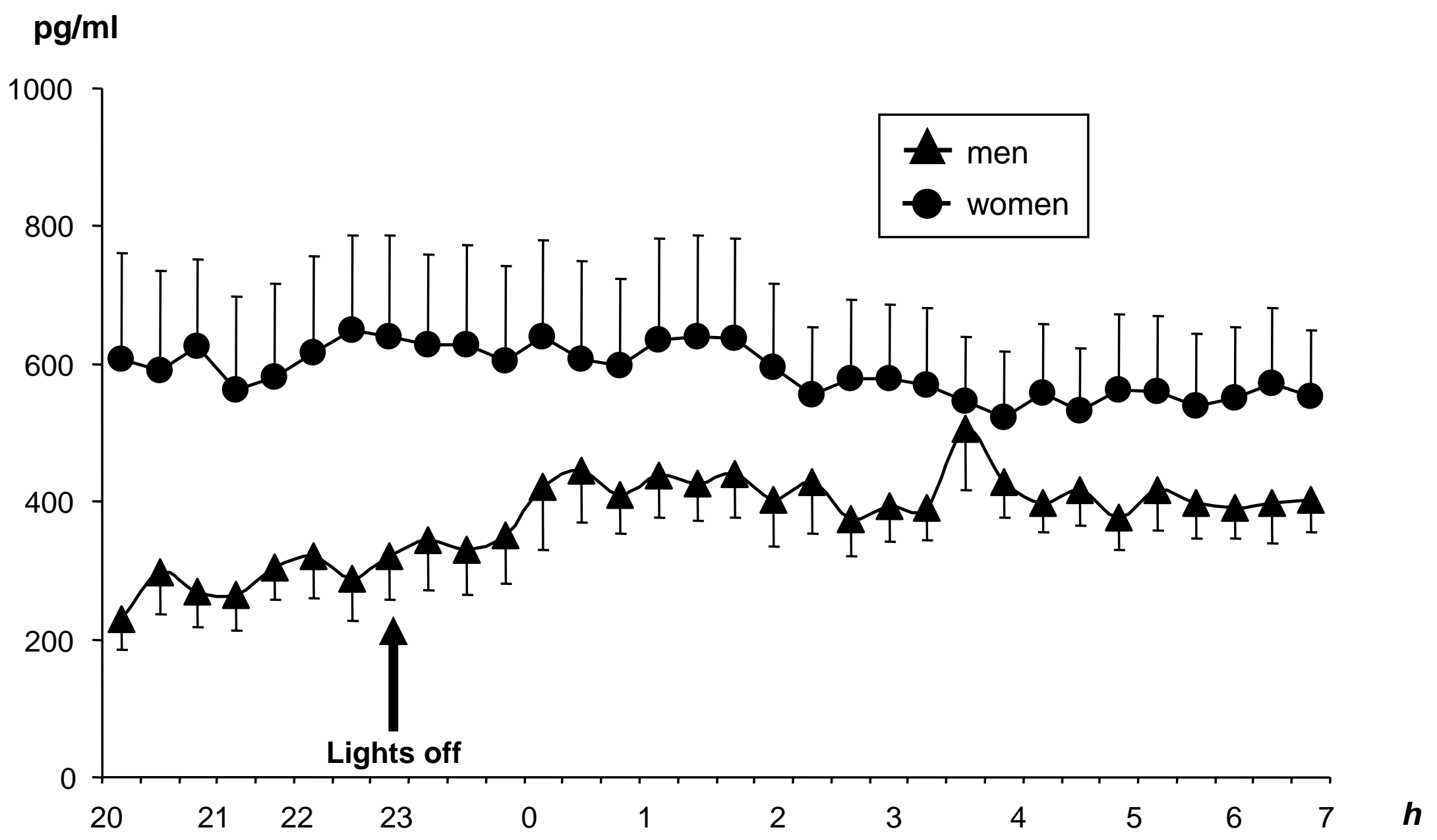


Fitigure 8

Cortisol plasma levels in depressed women

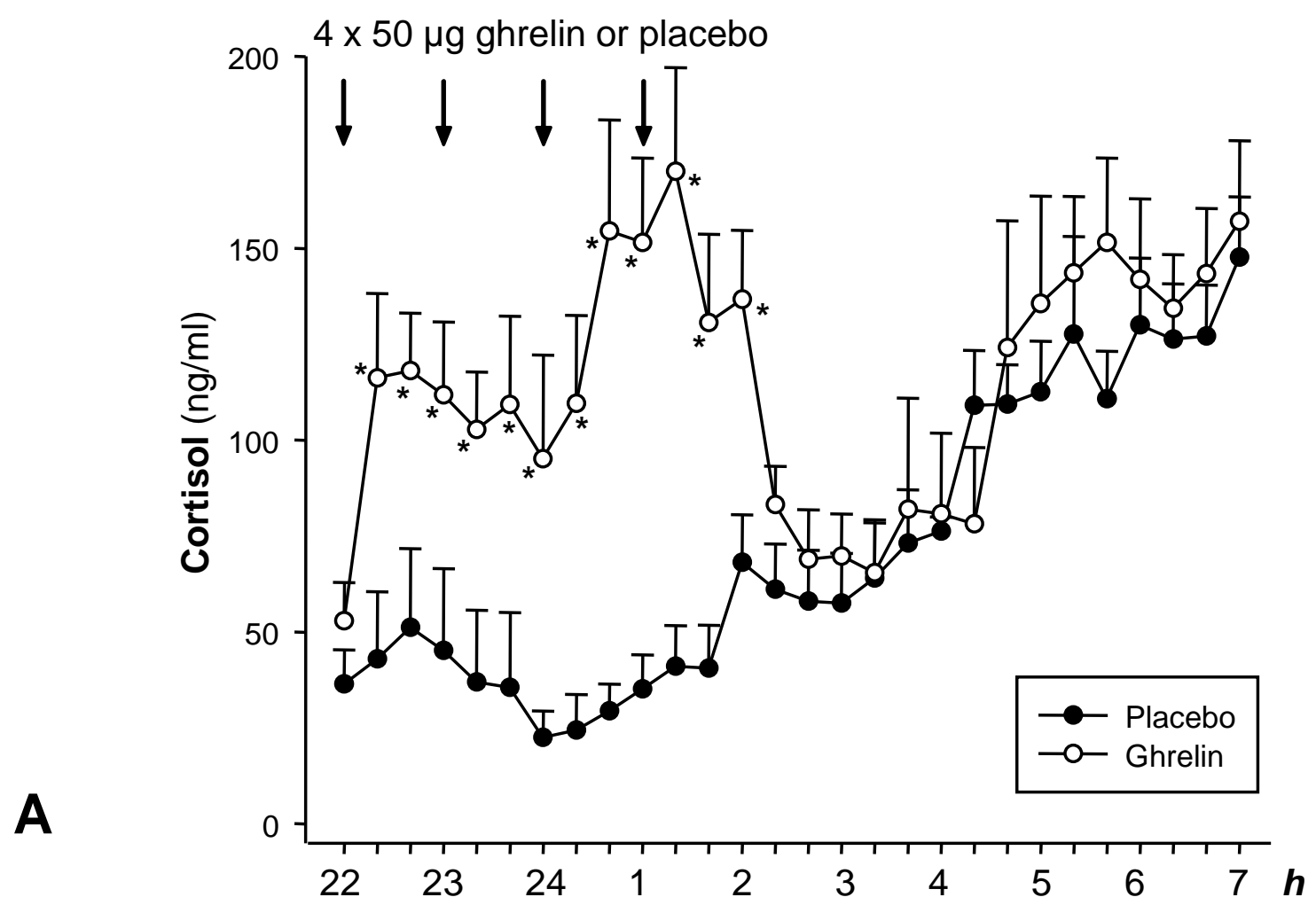

Cortisol plasma levels in depressed men



